\title{
International note: Confirmatory factor analysis and psychometric properties of the Youth Psychopathic Traits Inventory in a sample of Portuguese adolescents
}

\author{
Margarida Simões ${ }^{a}$,, José Lopes ${ }^{a}$, Rui Abrunhosa Gonçalves ${ }^{b}$ \\ ${ }^{a}$ University of Trás-os-Montes and Alto Douro, Portugal \\ b University of Minho, Portugal
}

\section{A R T I C L E I N F O}

\section{Article history:}

Available online xxx

\section{Keywords:}

Confirmatory factor analysis

Adolescence

Psychopathy

\begin{abstract}
A B S T R A C T
The aim of this paper was to test the factorial structure and evaluate the psychometric properties of the Youth Psychopathic Traits Inventory (YPI). The YPI is composed of 10 dimensions that further represent three hypothesized facets of the classical description of psychopathy: callousness, interpersonal manipulation and impulsiveness. A sample of 500 adolescents aged 12 to $18(M=14.87 ; S D=1.67)$ from northern Portugal participated in this study. The results generally confirmed the factorial structure of the YPI in this sample, with some qualifications.
\end{abstract}

(c) 2015 The Foundation for Professionals in Services for Adolescents. Published by Elsevier Ltd. All rights reserved.

\section{Introduction}

The Youth Psychopathic Traits Inventory (YPI; Andershed, Kerr, Stattin, \& Levander, 2002) aims to identify psychopathic traits among 12-18-year-olds. The YPI was derived from Cooke and Michie's (2001) three-factor model of psychopathy and was developed to overcome the deliberate manipulation of one's self-image, which can produce biased results. Therefore, its items are written in positive or neutral language (Lilienfeld \& Andrews, 1996).

According to Andershed et al. (2002), the YPI's factorial structure is similar to that of the Psychopathy Checklist Revised (PCL-R: Hare, 2003) according to Cooke and Michie (2001). The callous/unemotional dimension produces the least consistent results; in a study by Poythress, Dembo, Wareham, and Greenbaum (2006), the three-factor model was not replicated.

\section{Method}

Participants and procedure

The participants included $50012-18$-year-old adolescents $(M=14.87$; $S D=1.67)$ (all students invited to participate actually participated). The study was performed in the Northern District of Portugal. We selected two regular schools $(\mathrm{n}=262)$ and two professional schools $(\mathrm{n}=238)$.

This study was conducted after obtaining informed consent from parents and authorization from school boards.

\footnotetext{
* Corresponding author. Department of Education and Psychology, University of Trás-os-Montes and Alto Douro, 5001 - 558 Vila Real, Portugal.

E-mail address: margaridas@utad.pt (M. Simões).
} 
Table 1

Values corresponding to the CFA between items and dishonest charm, grandiosity, lying and manipulation first order factors.

\begin{tabular}{|c|c|c|c|}
\hline Dimensions & $\begin{array}{l}\text { Factorial saturations } \\
\text { (standardised direct effects) }\end{array}$ & $\begin{array}{l}\text { Construct/composite } \\
\text { reliability }\end{array}$ & $\begin{array}{l}\text { Variance } \\
\text { extracted \% }\end{array}$ \\
\hline $\begin{array}{l}\text { Dishonest charm } \\
\text { Indexes } \chi^{2}=6.46\end{array}$ & $\begin{array}{c}.60 \text { (it.6) to } .76 \text { (it.38) }(\mathrm{M}=.66)^{*} \\
\mathrm{FI}=.99+; \mathrm{NFI}=.99+; \mathrm{RMSEA}=.0\end{array}$ & $.79 / .98$ & 44 \\
\hline $\begin{array}{l}\text { Grandiosity } \\
\text { Indexes } \chi^{2}=7.65\end{array}$ & $\begin{array}{l}.51(\text { it.30 }) \text { to } .68(\text { it.37 })(\mathrm{M}=.61)^{*} \\
=.99+; \mathrm{NFI}=.99+; \mathrm{RMSEA}=.03\end{array}$ & $.75 / .97$ & 38 \\
\hline $\begin{array}{l}\text { Lying } \\
\text { Indexes } \chi^{2}=14.1\end{array}$ & $\begin{array}{l}.55\left(\text { it.7) to } .74(\mathrm{i} 43)(\mathrm{M}=.65)^{*}\right. \\
99+; \mathrm{NFI}=.98+; \mathrm{RMSEA}=.061+\end{array}$ & $.78 / .97$ & 42 \\
\hline $\begin{array}{l}\text { Manipulation } \\
\text { Indexes } \chi^{2}=48.4\end{array}$ & $\begin{array}{l}.57\left(\text { it.46)to } .84(\mathrm{i} 20)(\mathrm{M}=.69)^{*}\right. \\
\mathrm{CFI}=.95 ; \mathrm{NFI}=.94 ; \mathrm{RMSEA}=.13\end{array}$ & $.81 / .98$ & 48 \\
\hline
\end{tabular}

Note. it $=$ item; + reference values: $\chi^{2}<2$; CFI $>0.90$; RMSEA $<.08 ;$ NFI $>0.80 ;{ }^{*} \mathrm{t}>196, \mathrm{p}<.05$.

Table 2

Values Corresponding to the CFA Between Items and Remorselessness, Unemotionality and Callousness (first order factors).

\begin{tabular}{|c|c|c|c|}
\hline First order factors & $\begin{array}{l}\text { Factorial saturations } \\
\text { (standardised direct effects) }\end{array}$ & $\begin{array}{l}\text { Construct/composite } \\
\text { reliability }\end{array}$ & $\begin{array}{l}\text { Variance } \\
\text { extracted \% }\end{array}$ \\
\hline $\begin{array}{l}\text { Remorselessness } \\
\text { Indexes } \chi^{2}=4.58 \text {, }\end{array}$ & $\begin{array}{l}.49 \text { (it.8) to } .61(\text { it. } 48)(\mathrm{M}=.54) \\
\mathrm{CFI}=1,000 ; \mathrm{NFI}=.99 ; \mathrm{RMSEA}=0.000\end{array}$ & $.67 / .94$ & 30 \\
\hline $\begin{array}{l}\text { Unemotionality } \\
\text { Indexes } \chi^{2}=35.60\end{array}$ & $\begin{array}{l}.42(\text { it. } 2) \text { to } .56(\text { it. } 39)(\mathrm{M}=.48) \\
=5 ; \mathrm{CFI}=.86 ; \mathrm{NFI}=.85 ; \mathrm{RMSEA}=0.111\end{array}$ & $.97 / .90$ & 23 \\
\hline Callousness*(5it.) & -.052 (it.12) e .09 (it.17) to .73 (it.35) $(\mathrm{M}=.35)$ & $.41 / .70$ & .21 \\
\hline $\begin{array}{l}\text { Calloussness.(3it) } \\
\text { Mod. } 5 \text { items: Inde } \\
\text { Mod. } 3 \text { items: Inde }\end{array}$ & 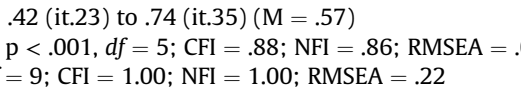 & $.58 / .81$ & .34 \\
\hline
\end{tabular}

Note. it $=$ item; reference values: $\chi^{2}<2 ;$ CFI $>.90 ;$ RMSEA $<.08$; NFI $>.80$.

${ }^{*} \mathrm{t}>1.96 ; \mathrm{p}<.05$.

\section{Measures}

The YPI contains 50 items; responses are given on a 4-point Likert scale ranging from "Does not apply at all” to “Applies very well" (Andershed et al., 2002). To construct the YPI, the authors started by creating 10 subscales of five items each that displayed good reliability. These 10 first-order factors corresponded to the classical description of psychopathy. Andershed et al. (2002) submitted these 10 first-order factors for principal component analysis (PCA) with Promax rotation, and three second-order factors, grandiose manipulative, callous/unemotional, and impulsivity and lack of sense of responsibility, were obtained from exploratory factorial analysis (EFA) and confirmatory factorial analysis (CFA; $\chi^{2}$ indexes) with structural equation modelling (SEM); this model displayed a good fit to the data (Comparative Fit Index $[\mathrm{CFI}]=0.98)$.

\section{Results}

CFA

CFAs with SEM were performed using variance-covariance matrices ( 50 items, 498 participants) to test the model fit of ten first-order factors and three second-order factors. These analyses were conducted in two steps. First, we analysed the fit among the observed variables, the items, and the first-order factors. Second, we analysed the fit between the first-order and second-order factors.

Table 3

Values corresponding to the CFA between items and thrill-seeking, impulsivity, lack of sense of responsibility first order factors.

\begin{tabular}{|c|c|c|c|}
\hline First order factors & $\begin{array}{l}\text { Factorial saturations } \\
\text { (standardised direct effects) }\end{array}$ & $\begin{array}{l}\text { Construct/composite } \\
\text { reliability }\end{array}$ & $\begin{array}{l}\text { Variance } \\
\text { extracted \% }\end{array}$ \\
\hline $\begin{array}{l}\text { Thrill-seeking } \\
\text { Indexes } \chi^{2}=74.214, \mathrm{p}<0.001\end{array}$ & $\begin{array}{l}.46(\text { it. } 4) \text { to } .69(\text { it. } 22)(\mathrm{M}=.57) \\
34 ; \mathrm{NFI}=.83 ; \mathrm{RMSEA}=.17\end{array}$ & $.70 / .95$ & 32 \\
\hline $\begin{array}{l}\text { Impulsivity } \\
\text { Indexes } \chi^{2}=12.734, p=0.025\end{array}$ & $\begin{array}{l}.37(\text { it.3) to } .68(\text { it. } 18)(\mathrm{M}=.50) \\
97 ; \mathrm{NFI}=.95 ; \mathrm{RMSEA}=.06\end{array}$ & $.63 / .92$ & 27 \\
\hline $\begin{array}{l}\text { Lack of sense of responsibility } \\
\text { Indexes } \chi^{2}=16.60, p=.0005 \text {, }\end{array}$ & $\begin{array}{l}.42(\text { it.13) to } .70(\text { it. } 16)(\mathrm{M}=.55) \\
7 ; \mathrm{NFI}=.97 ; \mathrm{RMSEA}=.05\end{array}$ & $.68 / .94$ & 31 \\
\hline
\end{tabular}

Note it $=$ item; + reference values: $\chi^{2}<2$; CFI $>0.90 ;$ RMSEA $<.08 ;$ NFI $>0.80 ;{ }^{*} \mathrm{t}>1.96, \mathrm{p}<.05$. 
Table 4

Factorial saturation values between the YPI second orders and first order factors.

\begin{tabular}{|c|c|c|c|c|c|c|}
\hline \multirow[t]{2}{*}{ First order factors } & \multirow[t]{2}{*}{ Variable } & \multicolumn{5}{|l|}{ Saturations } \\
\hline & & Non-standardised & Standardised & Standard error & $\mathrm{t}$ test & $\mathrm{p}$ \\
\hline \multirow[t]{4}{*}{ F2.1. Grandiose/manipulative } & Manipulation & 1.000 & .904 & & * & \\
\hline & Lying & .908 & .819 & .037 & 24.638 & $<.001$ \\
\hline & Grandiosity & .785 & .753 & .037 & 21.190 & $<.001$ \\
\hline & Disonest charm & .973 & .878 & .034 & 28.239 & $<.001$ \\
\hline \multirow[t]{3}{*}{ F2.2. Callous/unemotional } & Callousness & 1.000 & .118 & & $*$ & \\
\hline & Unemotionality & 5.232 & .779 & 2.162 & 2.420 & .016 \\
\hline & Remorselessness & 5.991 & .806 & 2.474 & 2.422 & .015 \\
\hline \multirow{3}{*}{$\begin{array}{l}\text { F3.3. Impulsive/lack of sense } \\
\text { of responsibility }\end{array}$} & Lack of sense of responsibility & 1.000 & .730 & & $*$ & \\
\hline & Impulsivity & .939 & .765 & .063 & 14.987 & $<.001$ \\
\hline & Thrill-seeking & 1.005 & .730 & .070 & 14.456 & $<.001$ \\
\hline
\end{tabular}

Note. * Parameter fixed to 1 , without the "t value".

Table 5

Covariance relation between the YPI second order factors.

\begin{tabular}{|c|c|c|c|c|c|}
\hline Second order factors & Second order factors & Standardised & Standard error & $\mathrm{t}$ test & $\mathrm{p}$ \\
\hline F2.1. Grandiose/manipulative & F2.2. Callous/unemotional & .801 & .014 & 2.390 & .017 \\
\hline F3.3. Impulsive/lack of sense of responsibility & F2.2. Callous/unemotional & .738 & .009 & 2.370 & .018 \\
\hline F3.3. Impulsive/lack of sense of responsibility & F2.1. Grandiose/manipulative & .758 & .016 & 10.643 & $<.001$ \\
\hline
\end{tabular}

For the fit indexes, we used the $\chi^{2}$ index, the CFI, the root mean square error of approximation (RMSEA) and the normed fit index (NFI). The following criteria were applied: $\chi^{2}<2$ (Tabachnick \& Fidell, 2001); CFI > 0.90; RMSEA $<0.08$; and NFI $>0.80$ (Arbuckle \& Wothke, 1999).

In Tables 1-3, all items displayed highly significant, positive associations with the tested first-order factors.

In Table 2, index values indicating good fit were observed for the factor remorselessness. However, the indices did not indicate good fit for unemotionality/callousness.

In Table 3, for the factors impulsivity and lack of sense of responsibility, the indexes, with the exception of the $\chi^{2}$ index, indicated good model fit.

As presented in Table 4, the factorial saturations were high and significant, varying between 0.73 and 0.90 , except for the relationship between the callous/unemotional second-order factor and the callousness first-order factor (0.118). In contrast, the covariance-standardized values between the second-order factors were high and significant (see Table 5).

Fig. 1 presents an overall model of the relationships between all first- and second-order factors.

\section{Discussion}

The overall model for the Portuguese version of the YPI was supported by the following fit indices: CFI, NFI and RMSEA. In a previous study by Andershed et al. (2002), a similar model was supported by the CFI and the non-NFI (NNFI; boys 0.98; girls

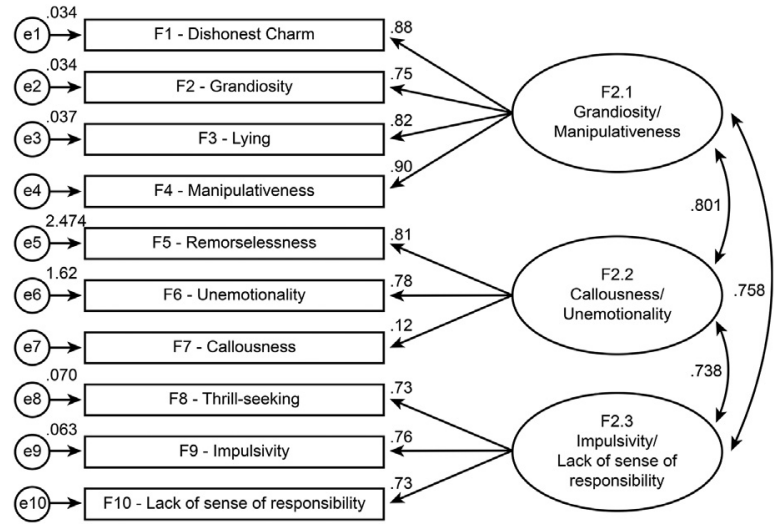

Fig. 1. Global model of the factorial structure of the YPI between the first order and the second order factors (standardised values). 
0.97 ) when gender was considered. The $\chi^{2}$ value was significant in the present study and in a validation study (Andershed et al., 2002).

Notably, when the fit indices between the items and the first-order factors were considered, all indices, including the $\chi^{2}$ value, indicated good model fit for dishonest charm and grandiosity. The remaining first-order factors, except for those referring to thrill expression and experience (thrill-seeking, unemotionality and callousness), were supported by the NFI. The measurement method used to determine the unidimensionality constitutes a study limitation. In that regard, rather than using the fixed-factor method described by Little (2013) for scaling latent factors, the factor loadings of marker indicators were freed and the factor variances were fixed at 1.00 . This modification permitted estimation of those parameters and avoided assigning metrics. As observed in previous studies (Andershed et al., 2002; Declercq, Markey, Vandist, \& Verhaeghe, 2009; Dolan \& Rennie, 2006), the overall dimension of callousness/unemotionality showed weak factor loading. The mean values obtained from these item responses were below the mean value of the scale; this result demonstrated that these factors did not indicate psychopathy.

\section{References}

Andershed, H., Kerr, M., Stattin, H., \& Levander, S. (2002). Psychopathic traits in non-referred youths: a new assessment tool. In E. Blaauw, \& L. Sheridan (Eds.), Psychopaths: Current international perspectives (pp. 131-158). The Hague: Elsevier.

Arbuckle, J., \& Wothke, W. (1999). Amos Vol. 4.0: User's guide. Chicago, IL: Smallwaters Corporation.

Cooke, D. J., \& Michie, C. (2001). Refining the construct of psychopathy: towards a hierarchical model. Psychological Assessment, 13, 171-188. http://dx.doi. org/10.1037/1040-3590.13.2.171.

Declercq, F., Markey, S., Vandist, K., \& Verhaeghe, P. (2009). The youth psychopathic traits inventory: factor structure and antisocial behavior in non-referred 12-17-year-olds. Journal of Forensic Psychiatry \& Psychology, 20, 1-18. http://dx.doi.org/10.1080/14789940802651757.

Dolan, M. C., \& Rennie, C. E. (2006). Reliability, validity, and factor structure of the Swedish Youth Psychopathic Trait Inventory in a UK sample of conduct disordered boys. Journal of Forensic Psychiatry \& Psychology, 17, 217-229. http://dx.doi.org/10.1080/14789940500497784.

Hare, R. D. (2003). The hare psychopathy checklist-Revised (2nd ed.). Toronto, ON, Canada: Multi-Health Systems.

Lilienfeld, S. O., \& Andrews, B. P. (1996). Development and preliminary validation of a self-report measure of psychopathic personality traits in noncriminal population. Journal of Personality Assessment, 66, 488-524. http://dx.doi.org/10.1207/s15327752jpa6603_3.

Little, T. D. (2013). Longitudinal structural equation modeling. New York: Guilford Press.

Poythress, N. G., Dembo, R., Wareham, J., \& Greenbaum, P. E. (2006). Construct validity of the Youth Psychopathic Traits Inventory (YPI) and the antisocial process screening device (APSD) with justice-involved adolescents. Criminal Justice and Behavior, 33, 26-55. http://dx.doi.org/10.1177/ 0093854805282518.

Tabachnick, B. G., \& Fidell, L. S. (2001). Using multivariate statistics (4th ed.). Boston: Allyn and Bacon. 